\title{
DINAMIKA KONSENTRASI PASAR INDUSTRI PERTELEVISIAN NASIONAL
}

\author{
Bestian Nainggolan \\ Pascasarjana Ilmu Komunikasi, Universitas Indonesia, Jl. Salemba Raya No. 4, Jakarta \\ 10430, Telp: (021) 3156941 \\ Email: djuli.bestian41@ui.ac.id
}

\begin{abstract}
:
The weakening macro condition of Indonesia's economy in the last five years has influenced the economic performance of the television media industry. Since that time, media advertising expenditure as the largest revenue source for the television industry has been declining. The purpose of this research is to know how each group of broadcast media corporations in this country are competing and trying to control the market of the media industry. Methods used in this research was adopting both the quantitative analysis which leans back upon the organization the field of industrial (in theory). Relying on the Structure-Conduct-Performance analysis model, the result of this research reveals that although the economic slowdown impacts the economic performance of the corporate group of television, the roles of three groups of television media corporations: Global Mediacom, Elang Mahkota Teknologi, and Visi Media Asia remain dominant. The market audience and television ads are concentrated in these three groups and build an increasingly uncompetitive structure for other industry players. This research contributes to give insight on the current economic situation of national television industry.
\end{abstract}

Keywords: capital, market, corporation, television industry

\begin{abstract}
Abstrak
Pelemahan kondisi makro perekonomian Indonesia lima tahun terakhir turut mempengaruhi kehidupan ekonomi industri media pertelevisian. Belanja iklan media sebagai sumber penghasilan terbesar industri pertelevisian pertumbuhannya mulai menurun dalam kurun waktu tersebut. Tujuan penelitian ini adalah untuk memaparkan bagaimana masing-masing grup korporasi media penyiaran di negeri ini saling bersaing dan berupaya menguasai pasar industri media. Metode penelitian yang digunakan dalam penelitian ini adalah menggunakan pendekatan analisis kuantitatif yang bersandar pada Industrial Organization (IO theory). Bersandar pada model analisis Structure-ConductPerformance, hasil penelitian ini mengungkapkan kinerja ekonomi grup korporasi pertelevisian mengalami perlambatan ekonomi. Peran tiga grup korporasi media pertelevisian: Grup Global Mediacom, Elang Mahkota Teknologi, dan Visi Media Asia, tetapdominan. Pasar audiens dan iklan pertelevisianterkonsentrasi pada ketiga grup tersebut dan membangun struktur persaingan yang semakin tidak kompetitif bagi pelaku industri lainnya. Kontribusi penelitian ini adalah memberikan wawasan mengenai kondisi ekonomi industri pertelevisian nasional saat ini.
\end{abstract}

Kata Kunci: kapital, pasar, korporasi, industri pertelevisian

\section{Pendahuluan}

Tekanan faktor eksternal global terhadap kondisi perekonomian Indonesia kurun lima tahun terakhir masih signifikan dirasakan. Laju perekonomian dunia yang melambat, ditandai penurunan gerak perekonomian negaranegara berpengaruh seperti Tiongkok, Jepang, Amerika Serikat, maupun negara-negara kawasan Eropa Barat, secara langsung turut menghambat ruang gerak ekonomi, khususnya ekspor Indonesia (Prasetyantoko, 2014; Basri, 2015; Djiwandono, 2015).

Di sisi lain, kekuatan internal perekonomian bangsa ini untuk bertumbuh secara mandiri masih lemah. Berbagai aktivitas usaha perekonomian yang dilakukan seperti belanja barang dan modal pemerintah, konsumsi rumah tangga, impor barang dan 
modal, dan kegiatan ekonomi lainnya belum cukup mampu menanggalkan tekanan eksternal yang dihadapi (Basri, 2017).

Menggunakan indikator Produk Domestik Bruto (PDB) sebagai acuan, pencatatan Badan Pusat Statistik (BPS) menunjukkan, semenjak awal 2011 hingga akhir tahun 2016 berlangsung tren penurunan pertumbuhan perekonomian. Pada kuartal pertama tahun 2011, negeri ini masih mencatatkan pertumbuhan sekitar 6,5 persen. Namun selepas itu, pertumbuhan ekonomi cenderung melambat. Hingga akhir tahun 2017, derajat pertumbuhan masih berkisar pada 5 persen, di bawah rata-rata pertumbuhan lima tahun lalu.

Secara khusus, perlambatan pertumbuhan juga terjadi pada sektor komunikasi dan informasi. Lebih spesifik lagi, pada industri pertelevisian. Sebenarnya, jika mencermati pasar industri, selama ini kehidupan ekonomi industri pertelevisian yang ditopang oleh industri periklanan ini tergolong berlimpah kapital. Data Nielsen (2017) menunjukkan sedikitnya tiga perempat dari total pasar iklan industri media terserap pada dunia pertelevisian nasional yang terdistribusikan pada hanya 15 pelaku usaha pertelevisian. Pada tahun 2011 diperkirakan sebesar $\mathrm{Rp}$ 44,06 trilyun nilai belanja iklan yang terserap pada industri pertelevisian. Setahun kemudian, meningkat menjadi Rp 53,7 trilyun. Lima tahun berikutnya, meningkat hampir dua kali lipat, mencapai Rp 85,16 trilyun. Hanya, pada tahun 2016 menurun menjadi Rp 72,9 trilyun.

Sekalipun dari waktu ke waktu volume belanja iklan meningkat (kecuali di tahun 2016), ternyata pertumbuhan pasar iklan pertelevisian sepanjang lima tahun terakhir menunjukkan perlambatan. Mengambil rentang acuan 2011-2016, puncak pertumbuhan iklan terjadi di tahun 2013, sebesar 26,3 persen. Tahun-tahun selanjutnya melambat, bahkan sepanjang tahun 2016 terjadi penurunan signifikan hingga minus 14 persen dari tahun sebelumnya.

Perlambatan laju perekonomian yang diikuti oleh perlambatan pertumbuhan iklan industri pertelevisian mengindikasikan potensi ancaman yang mengkhawatirkan terhadap prospek bisnis pertelevisian di negeri ini. Menjadi semakin mengkhawatirkan tatkala sumber revenue paling dominan pada industri pertelevisian diperoleh dari penyediaan ruang penyiaran bagi periklanan. Oleh karena itu, penurunan pertumbuhan belanja iklan secara langsung meredupkan kehidupan bisnis industri pertelevisian.

Pada pemandangan lain, seperti juga produk media massa lainnya, industri televisi tengah dihadapkan pada kemunculan media digital berbasis internet, seperti media online dan media sosial yang memberikan tawaran subtitusi produk. Dari sisi permintaan (demand side), pertumbuhan signifikan penggunaan internet di Indonesia dari perkiraan sebesar 55 juta di tahun 2011 menjadi 132,7 juta pada tahun 2016 (APJII, 2017), diikuti oleh kemunculan produsen informasi (supply side) yang menurut data Dewan Pers (2017) kini terdapat 47 ribu media di Indonesia. Dari jumlah tersebut, sekitar 44.300 merupakan media online.

Pada pasar industri media, kehadiran produk subtitusi di atas semakin memperketat peta persaingan, terutama dalam perebutan iklan sebagai sumber utama revenue. 
Sekalipun, saat ini penguasaan media internet masih relatif kecil. Berdasarkan hasil kajian Price Waterhouse Cooper (PwC) terbaru (2017) industri televisi masih dominan, tetap paling populer. Gambaran pada tahun 2016 lalu, misalnya, proporsi iklan media internet mencapai 13,1 persen dari total seluruh iklan dalam berbagai media di negeri ini. Sementara televisi mencapai 53,6 persen. Bahkan prediksi PwC di tahun 2021, sekalipun media internet mampu meningkat menjadi 21,5 persen, televisi tetap dominan menguasai 53,8 persen belanja iklan.

Di tengah dinamika yang berlangsung, menjadi pertanyaan bagaimanakah konfigurasi struktur pasar (market structure) industri pertelevisian di negeri ini? Pelaku-pelaku pasar industri siapa saja yang tergolong sebagai penguasa pasar dan sebaliknya seberapa besar ruang yang tersisa bagi pelaku pasar lainnya? Demikian pula, seberapa jauh dinamika yang berlangsung turut mempengaruhi kinerja usaha (market performance) dari masingmasing pelaku industri pertelevisian?

Berbagai persoalan di atas menjadi pertanyaan yang menarik dikaji mengingat industri pertelevisian merupakan penggerak terbesar dari total nilai ekonomi yang disumbangkan oleh industri media di negeri ini. Dari sisi belanja iklan nasional, misalnya, kajian Nielsen Advertising Expenditure (2016) terhadap 15 stasiun televisi, 98 koran, serta 120 majalah dan tabloid, menunjukkan total belanja iklan di televisi dan media cetak sudah mencapai Rp 134,8 triliun. Suatu jumlah yang tergolong signifikan, yang proporsi mencapai 1 persen Produk Domestik Bruto (PDB) Indonesia.
Di sisi lain, sebagai media komunikasi, pertelevisian merupakan media yang paling banyak dijangkau oleh penduduk negeri ini. Dengan potensi penetrasi hingga lebih dari 90 persen wilayah di negeri ini, televisi potensial menjadi media komunikasi yang paling signifikan mempengaruhi kehidupan masyarakat, baik kehidupan sosial ekonomi maupun politik (Ishadi, 2002; Kitley, 2003; Hollander, dkk, 2009).

Besarnyakapitalyang dikelola dan begitu pula terhadap pengaruh sosial politik yang ditimbulkannya, menjadikan keberadaan dan fungsi penyiaran pertelevisian sangat strategis di negeri ini. Sisi strategis ini pula yang menjadi daya tarik bagi tiap-tiap pelaku industri untuk berkecimpung dalam bisnis pengelolaan televisi.

Kendala teknis sumber daya frekuensi (technical barrier to entry) membuat praktik pengelolaan industri pertelevisian (penyiaran) bersifat terbatas. Tidak seperti karakteristik industri media lainnya, limitasi sumber daya frekuensi industri televisi berimplikasi pada keterbatasan peluang kepemilikan dan pengelolaan. Hanya dalam praktik industri, keterbatasan sumber daya frekuensi tidak selalu berkonsekuensi pada keadilan dan pemerataan kepemilikan dan pengelolaan.

Faktamenunjukkanterjadipengintegrasian kepemilikan media baik secara horisontal, vertikal, maupun diagonal. Grup Global Mediacom, misalnya, membawahi Grup MNC yang mengoperasionalkan stasiun televisi RCTI, Global TV, MNCTV, dan Inews TV. Grup Elang Mahkota Teknologi (EMTEK) membawahi Grup Surya Citra Media yang mengendalikan operasional SCTV dan 
Indosiar. Begitu pula Grup Visi Media Asia termasuk di dalamnya Intermedia Capital yang mengelola ANTV dan TVOne atau Grup Trans Media atau CT Corp dengan TRANS TV serta TRANS7.

Di luar grup korporasi media tersebut juga masih terdapat beberapa grup korporasi media lainnya, seperti Grup Kompas Gramedia, Grup Jawa Pos, dan lainnya yang turut mengembangkan kapital media yang dikuasai ke dalam bentuk kapital media pertelevisian. Secara keseluruhan di Indonesia, dalam kajian Lim (2012) dan Nugroho, Putri, dan Laksmi (2012), terdapat 12 hingga 13 kelompok media besar yang mengendalikan hampir semua kanal media, baik penyiaran, cetak, dan media online.

Pada kajian ekonomi industri media, pengintegrasian kepemilikan media, baik secara horisontal, vertikal, maupun diagonal dapat dibaca sebagai bagian dari strategi pengkonsolidasian kapital dalam upaya penguasaan pasar dan penciptaan surplus nilai produksi atau profit (Picard, 1989; Albaran, 1996, 2010). Konsep ekonomi politik media menunjukkan bahwa pengintegrasian tidak lebih sebagai suatu langkah spasialisasi yaitu suatu upaya korporasi dalam menguatkan rentang kendali terhadap ruang dan waktu (Mosco, 1996, 2009). Knoche (1989) dalam era perubahan teknologi saat ini menganggapnya sebagai bagian dari praktik kapitalisme industri media yang tengah bertransformasi secara struktural ke dalam format universalisme media.

Dampak dari universalisme media ataupun pengintegrasian kepemilikan mendorong terbentuknya struktur pasar industri media yang semakin distortif (Picard, 1989; Albaran, 1996). Pola kompetisi dalam struktur pasar industri yang terbentuk menjadi semakin terkonsentrasi pada kekuatan grup korporasi terintergratif, persaingan menjadi tidak kompetitif dan bergerak menjadi semakin oligopolistik. Dengan perkataan lain, universalisme media yang kini tengah berlangsung justru membangun entry barrier yang tidak memberikan ruang bagi para pelaku industri lain untuk menikmati transaksi pasar industri secara sehat dan berkeadilan.

Pada konteks semacam ini, menjadi signifikan ditelaah bagaimana struktur pasar dan kinerja pasar industri pertelevisian yang terbentuk saat ini di tengah berbagai upaya pengintegrasian kepemilikan media maupun tekanan ekonomi yang berlangsung.

Berdasarkan pemaparan latar belakang, tujuan penelitian ini adalah untuk memaparkan bagaimana masing-masing grup korporasi media penyiaran di negeri ini saling bersaing dan berupaya menguasai pasar industri media

\section{Metode Penelitian}

Pada kajian ini, perspektif ekonomi industri media menjadi pijakan dalam mendeskripsikan dan mengekplorasikan kondisi ekonomi industri pasar pertelevisian di negeri ini. Sebanyak 15 stasiun penyiaran televisi yang selama ini tergolong signifikan dalam penguasaan pasar iklan dan audiens nasional dikaji. Seluruhpelaku industri tersebut(kecuali TVRI sebagai televisi publik) tergabung dalam 8 (delapan) grup kepemilikan media, yaitu: Grup Global Mediacom termasuk di dalamnya Grup MNC (RCTI, Global TV, MNCTV, Inews TV), Grup Elang Mahkota Teknologi 
termasuk di dalamnya Grup Surya Citra Media (SCTV, Indosiar), Grup Visi Media Asia termasuk di dalamnya Intermedia Capital (ANTV, TVOne), Grup Trans Media atau CT Corp (TRANS TV, TRANS7), Grup Media (METRO TV), Grup Kompas Gramedia (Kompas TV), Grup Rajawali Corporation (RTV), dan Grup Indika (NET).

Mengkaji karakteristik pasar industri media digunakan pendekatan analisis kuantitatif yang bersandar pada Industrial Organization (IO theory). Analisis ekonomi media semacam ini dilakukan untuk mencermati kondisi Market Structure-Market Conduct-Market Performance (SCP). Melalui model analisis ini, fokus kajian pada bagaimana suatu satuan unit bisnis (grup korporasi media pertelevisian) sebagai pelaku industri media menentukan strategi dan kebijakan industrialnya (market conduct) dalam merespons struktur pasar industri yang terbentuk (market concentration dan market competition), dan bagaimana strategi dan kebijakan yang diterapkan itu pada akhirnya turut membentuk struktur pasar industri media (Albarran, 1996, 2002; 2010:29-41; Young, 2000; Wirth \& Bloch, 1995). Konsepsi pasar industri media yang dimaksud merujuk pada karakteristik pasar industri media yang terdiri dari pasar audiens dan pasar iklan (Picard, 1989).

Pencermatan terhadap Market Structure industri media televisi digunakan model pengukuran pola konsentrasi pasar (market concentration) dan kompetisi pasar (market competition). Pengukuran Rasio Konsentrasi (Concentration Ratio) digunakan dengan menghitung penguasaan pasar empat pe- laku besar industri (CR4) (Albarran \& Mierzejewska, 2004:2-4). Khusus terhadap kinerja pasar (market performance) dilakukan pengukuran terhadap kinerja pertumbuhan (growth) dan profitabilitas (profitability) usaha yang dijalankan.

Berdasarkan analisis terhadap struktur pasar industri media pertelevisian, baik pasar audiens (share audiens tahunan masingmasing stasiun televisi) dan periklanan (pencatatan tahunan belanja iklan media setiap televisi) kajian ini menempatkan tiga pelaku industri (the big three), yaitu Grup MNC, Grup Elang Mahkota Teknologi, dan Grup Visi Media Asia menjadi penguasa pasar. Selanjutnya, dari ketiga grup korporasi tersebut dianalisis kinerja keuangan korporasinya.

Data terkait dengan share audiens maupun belanja iklan tiap-tiap stasiun televisi diperoleh dari pencatatan Nielsen sepanjang tahun analisis. Data berupa kinerja keuangan tiap-tiap pelaku industri seperti besaran dan pertumbuhan aset, revenue, hingga profit yang dihimpun dari laporan tahunan dan keuangan perusahaan (teraudit) dengan periode semenjak tahun 2011 hingga 2017.

\section{Hasil Penelitian dan Pembahasan}

Semenjak kebijakan Open Sky pertelevisian 1986 digulirkan, dinamika ekonomi industri pertelevisian semakin semarak. Kebijakan yang membuka ruang penyelenggaraan siaran pertelevisian melalui satelit dan jaringan kabel tersebut mengijinkan kehadiran pihak swasta sebagai penyelenggaran penyiaran televisi. (Armando, 2016; Kitley, 2003; Ishadi, 2002; Sen \& Hill, 2000).

Pertimbangannya, dengan membuka ruang penyelenggaraan pertelevisian selain 
yang dikelola pemerintah maka ekonomi yang akan semakin bergairah. Acuannya, pertama, teknologi satelit yang digunakan dalam pendistribusian siaran televisi akanmemicu penciptaan konsumen media pertelevisian yang diikuti oleh peningkatan penggunaan dan penjualan pesawat televisi di seluruh negeri. Kedua, kebijakan dikeluarkanbersamaan dengan situasi bisnis dalam negeri yang tengah meningkat pesat. Industri media pun ikut dipastikan merasakannya terkait dengan ruang iklan yang disediakan. Ketiga, kebijakan tersebut mengundang ketertarikan para pebisnis nasional dalam membangun pasar industri baru sekaligus mencegah investor asing memasuki pasar pertelevisian nasional (Sen \& Hill, 2000:114).

Hasil kebijakan tersebut, antara tahun 1989 hingga 1995 muncul gelombang pertama pertelevisian swasta komersil, sejalan dengan kehadiran RCTI (1987), SCTV (1989), TPI (1990) selanjutnya menjadi MNCTV (2010), ANTV (1993), dan Indosiar (1995). Kehadiran lima stasiun tersebut diikat dengan beragam peraturan, antara lain kehadiran stasiun penyiaran televisi swasta dimaksudkan pula sebagai pendukung UUD 1945, Pancasila, pembangunan nasional, dan pencegahan penyiaran bersinggungan dengan doktrin Suku, Agama, Ras, dan Antar-golongan (SARA). Sebagian dari revenue iklan dikontribusikan pada TVRI. Tidak dapat menyelenggarakan siaran berita (hanya TVRI). Para pemegang ijin penyiaran televisi komersil tersebut saat itu diberikan pada para pebisnis yang tergolong keluarga atau memiliki kedekatan dengan Presiden Suharto (Hollander, dkk, 2009:41; Armando 2016:141-162)
Perubahan rezim pemerintahan Presiden Soeharto 1998 mengubah tatanan dan regulasi industri media. Perijinan pendirian media cetak (SIUPP) dihilangkan (1998), Departemen Penerangan sebagai regulator dan pengontrol kehidupan media dibubarkan (1999), kemunculan undang-undang baru mengenai pers (UU 40 Tahun 1998) dan undang-undang penyiaran (UU 32 Tahun 2002) memberikan ruang kebebasan pendirian media. Industri pertelevisian turut menikmati liberalisasi tersebut. Di antara tahun 2000-2002 muncul lima stasiun televisi baru: Metro TV (2000), Global TV (2001), Lativi (2001) diakuisisi Grup Bakrie, berganti nama menjadi TVOne (2008), Trans TV (2001), TV7 (2001) yang selanjutnya merger dengan grup Trans, berubah nama menjadi Trans7 (2006).

Sejalan dengan kemunculan televisi berjaringan dengan frekuensi lokal, pelaku baru industri pertelevisian bermunculan. Grup Kompas Gramedia, setelah sebelumnya melepas TV 7 pada Grup Trans Corp, tahun 2011 meluncurkan Kompas TV. Grup Jawa Pos yang menguasai perijinan televisi lokal mengudarakan Jawa Pos TV. Grup Rajawali Corpora tahun 2012 mengambil alih TV lokal B-Channel dan mengubah RTV (2014). Grup Indika yang sebelumnya pernah tercatat sebagai salah satu pemegang saham SCTV, mengambil alih TV anak Spacetoon dan menggantinya menjadi NET TV (2013).

Pada perjalannnya, sebagian stasiun televisi beralih kepemilikan dan sebagian lainnya tergolong agresif didalam mengembangkan bisnis melalui ekspansi kapital yang terintegrasi secara horizontal, vertikal, maupun 
diagonal (cross media integration). Kini, setidaknya terdapat 15 stasiun televisi yang tergolong signifikan keberadaannya.

Jika dicermati lebih jauh, di balik upaya pengembangan kapital media masingmasing grup korporasi tersebut, terdapat dinamika persaingan di dalam penguasaan pasar audiens penonton dan iklan. Namun, berdasarkan pada penguasaan pasar audiens dan iklan, dari keseluruhan grup korporasi media yang bersaing, tampak hanya tiga grup korporasi yaitu Grup Global Mediacom, Elang Mahkota Teknologi, dan Visi Media Asia, yang sejauh ini dominan (Tabel 1).
Pada tahun 2016, melalui seluruh televisi yang dikendalikannya, ketiga grup korporasi media tersebut mampu menguasai hingga 75 persen penonton televisi. Porsi terbesar dikuasai oleh Grup Global Mediacom, sebesar 35 persen, diikuti oleh Grup EMTEK (22,8 persen), dan Grup Visi Media Asia (17,3 persen). Besarnya penguasaan ketiga grup korporasi media tersebut dari waktu ke waktu tampak semakin membesar. Pada tahun 2012, ketiganya masih menguasai sebesar 70 persen. Adanya peningkatan proporsi penguasaan tersebut, struktur pasar audiens industri pertelevisian negeri ini tampak sangat

Tabel 1. Proporsi Penguasaan Pasar Audiens Grup Korporasi Televisi

\begin{tabular}{|c|c|c|c|c|c|c|}
\hline \multirow[t]{2}{*}{ No } & \multirow{2}{*}{$\begin{array}{l}\text { Grup Korporasi dan Stasiun } \\
\text { Televisi }\end{array}$} & \multicolumn{5}{|c|}{ Audience Share (\%) } \\
\hline & & 2012 & 2013 & 2014 & 2015 & 2016 \\
\hline \multirow[t]{6}{*}{ I } & Grup Global Mediacom & & & & & \\
\hline & RCTI & 15,5 & 17 & 14,3 & 15,2 & 17,7 \\
\hline & MNC TV & 13,4 & 10,8 & 9,1 & 10,3 & 10,4 \\
\hline & GLOBAL & 6,7 & 7 & 5,9 & 6,4 & 5,2 \\
\hline & INEWS TV & 0 & 0 & 0 & 0,8 & 1,7 \\
\hline & Total & 35,6 & 34,8 & 29,3 & 32,7 & 35,0 \\
\hline II & Grup Elang Mahkota Teknologi & & & & & \\
\hline 1 & SCTV & 14,9 & 15,9 & 16,2 & 14,4 & 11,5 \\
\hline \multirow[t]{2}{*}{2} & INDOSIAR & 9,5 & 8,2 & 11,3 & 12,3 & 11,3 \\
\hline & Total & 24,4 & 24,1 & 27,5 & 26,7 & 22,8 \\
\hline III & Grup Visi Media Asia & & & & & \\
\hline 1 & ANTV & 6,9 & 6,7 & 11,2 & 11,4 & 14 \\
\hline \multirow[t]{2}{*}{2} & TVONE & 3,8 & 4,3 & 4,5 & 3,5 & 3,3 \\
\hline & Total & 10,7 & 11,0 & 15,7 & 14,9 & 17,3 \\
\hline IV & Grup Trans Media & & & & & \\
\hline 1 & TRANS7 & 11,9 & 10,8 & 7,9 & 7,5 & 7,7 \\
\hline \multirow[t]{2}{*}{2} & TRANS & 11,2 & 12 & 10,3 & 7,1 & 5,9 \\
\hline & Total & 23,1 & 22,8 & 18,2 & 14,6 & 13,6 \\
\hline \multirow{7}{*}{. } & Grup Media Lainnya & & & & & \\
\hline & NET & 0 & 0,7 & 1,5 & 2,9 & 3,2 \\
\hline & METRO & 2,1 & 2 & 2,6 & 2,3 & 1,9 \\
\hline & RTV & 0 & 0 & 0,7 & 1,2 & 1,5 \\
\hline & KOMPAS TV & 0 & 0 & 0,5 & 0,9 & 1,4 \\
\hline & TVRI & 0,9 & 1,2 & 1,3 & 1,3 & 1,2 \\
\hline & Total & 3,0 & 3,9 & 6,6 & 8,6 & 9,2 \\
\hline
\end{tabular}

(Sumber: Diolah penulis dari data Nielsen Media 2012-2016) 
terkonsentrasi (high concentration) dan pola persaingan yang terbentuk kurang kompetitif, cenderung bersifat oligopolistik.

Kondisi yang tidak berbeda pada pasar iklan pertelevisian. Penguasaan ketiga grup korporasi media tersebut tampak dominan. Penguasaan ketiganya juga mencapai 75 persen. Grup Global Mediacom tahun 2016 lalu menguasai hingga 34,4 persen, diikuti oleh Grup Emtek (24 persen), dan Grup Visi Media Asia (17 persen). Pelaku utama industri televisi lainnya, seperti Grup Trans Corp masih menguasai hingga 16 persen dan grup media lainnya masih tergolong kurang signifikan, total di bawah 10 persen (Tabel 2).

Apabila penguasaan audiens ketiga grup korporasi media tersebut dari waktu ke waktu semakin membesar, dari sisi pasar iklan relatif tetap pada kisaran 74-78 persen. Dengan besaran tersebut, struktur pasar iklan industri pertelevisian terlihat sangat terkonsentrasi (high concentration) dan pola persaingan yang tidak kompetitif, cenderung bersifat oligopolistik.

Kondisi pasar audiens dan iklan yang terbentuk kurun lima tahun terakhir ini

Tabel 2. Penguasaan Pasar Iklan Grup Korporasi Televisi

\begin{tabular}{|c|c|c|c|c|c|c|c|}
\hline \multirow[t]{2}{*}{ No } & \multirow[b]{2}{*}{ Grup Korporasi dan Stasiun Televisi } & & \multicolumn{5}{|c|}{ Share Penerimaan Iklan (\%) } \\
\hline & & & 2012 & 2013 & 2014 & 2015 & 2016 \\
\hline I & Grup Global Mediacom & & & & & & \\
\hline 1 & $\mathrm{RCTI}$ & & 15,9 & 15,9 & 15,0 & 15,0 & 15,0 \\
\hline 2 & MNC TV & & 14,2 & 14,9 & 13,6 & 12,2 & 11,2 \\
\hline 3 & GLOBAL & & 7,8 & 7,0 & 8,3 & 7,8 & 7,2 \\
\hline 4 & INEWS TV & & 0,0 & 0,0 & 0,0 & 0,5 & 0,9 \\
\hline & & Total & 37,9 & 37,9 & 36,8 & 35,5 & 34,3 \\
\hline II & Grup Elang Mahkota Teknologi & & & & & & \\
\hline 1 & SCTV & & 13,6 & 14,3 & 12,8 & 12,9 & 12,9 \\
\hline 2 & INDOSIAR & & 9,2 & 9,7 & 9,2 & 10,4 & 11,1 \\
\hline & & Total & 22,8 & 24,0 & 22,0 & 23,3 & 24,0 \\
\hline III & Grup Visi Media Asia & & & & & & \\
\hline 1 & ANTV & & 8,2 & 8,5 & 10,4 & 9,6 & 10,7 \\
\hline 2 & TVONE & & 7,0 & 7,3 & 7,7 & 6,5 & 6,3 \\
\hline & & Total & 15,2 & 15,8 & 18,1 & 16,1 & 17,0 \\
\hline IV & Grup Trans Media & & & & & & \\
\hline 1 & TRANS7 & & 10,5 & 9,8 & 7,8 & 7,9 & 8,3 \\
\hline 2 & TRANS & & 9,6 & 8,7 & 8,1 & 6,5 & 7,6 \\
\hline & & Total & 20,2 & 18,5 & 15,8 & 14,4 & 15,9 \\
\hline $\mathrm{V}$ & Grup Media Lainnya & & & & & & \\
\hline 1 & NET & & 0,0 & 0,1 & 0,5 & 1,6 & 1,6 \\
\hline 2 & METRO & & 3,7 & 3,5 & 4,7 & 5,0 & 3,9 \\
\hline 3 & RTV & & 0,0 & 0,0 & 1,0 & 1,7 & 1,5 \\
\hline 4 & KOMPAS TV & & 0,0 & 0,0 & 0,9 & 2,3 & 1,7 \\
\hline 5 & TVRI & & 0,2 & 0,2 & 0,2 & 0,2 & 0,2 \\
\hline & & Total & 3,9 & 3,8 & 7,2 & 10,7 & 8,8 \\
\hline
\end{tabular}

Keterangan: Belanja iklan berdasarkan Gross Rate Card

Sumber: Diolah dari data Nielsen Media 2012-2016 
menarik dicermati. Perlambatan kondisi perekonomian nasional yang diikuti oleh penurunan laju pertumbuhan iklan pertelevisian beberapa tahun terakhir ini ternyata tidak mampu mengubah struktur pasar yang terbentuk. Bahkan, berdasarkan pada kedua kondisi pasar pertelevisian di atas, penguasaan tiga grup pelaku pasar menjadi semakin dominan dan membuat pola persaingan pasar menjadi semakin tidak kompetitif.

Sekalipun struktur pasar pertelevisian terlihat kurang kompetitif, terkuasai oleh sedikit grup korporasi, tidak berarti ruang penguasaan pasar tertutup rapat. Jika diamati, dinamika persaingan di antara para pelaku pasar terjadi terutama pada tahuntahun terakhir ini. Demikian pula jika diamati pola penguasaan pasar dan kinerja dari masing-masing pelaku pasar, termasuk tiga grup korporasi penguasa industri televisi, beberapa tahun belakangan ini tampak dinamis.

Grup Global Mediacom, sekalipun selama ini terlihat sebagai pemimpin pasar industri pertelevisian, semenjak tahun 2012 hingga kini dihadapkan pada kecenderungan penurunan proporsi penguasaan iklan. Kondisi tersebut semakin menjadi ancaman tatkala upaya yang dilakukan selama ini dalam meningkatkan share audiens (semenjak tahun 2014) tidak berbuah pada peningkatan proporsi iklan mereka (Gambar 1).

Kecenderungan proporsi penurunan iklan semakin dikuatkan dengan kinerja keuangan grup korporasi ini. Jika sebelumnya grup ini mampu mewujudkan peningkatan aset, revenue, hingga profit dari waktu ke waktu, namun semenjak tahun 2014 menghadapi tekanan yang signifikan. Profit dari grup ini menurun tajam di tahun 2015. Sekalipun meningkat kembali di tahun 2016, namun belum mampu mengulang kejayaannya dalam penciptaan profit di tahun 2012. Bahkan terbaru, hingga triwulan ke-3 (September 2017), profit yang diraih baru mencapai Rp 915,1 milyar, atau baru sekitar 61 persen dari pencapaian profit sepanjang tahun 2016 lalu. Kondisi demikian mengindikasikan penurunan kinerja dibandingkan tahun 2016.

Penurunan profit disebabkan oleh pendapatan usaha grup ini yang juga merosot semenjak tahun 2014 dan demikian juga dengan besaran aset yang menurun semenjak

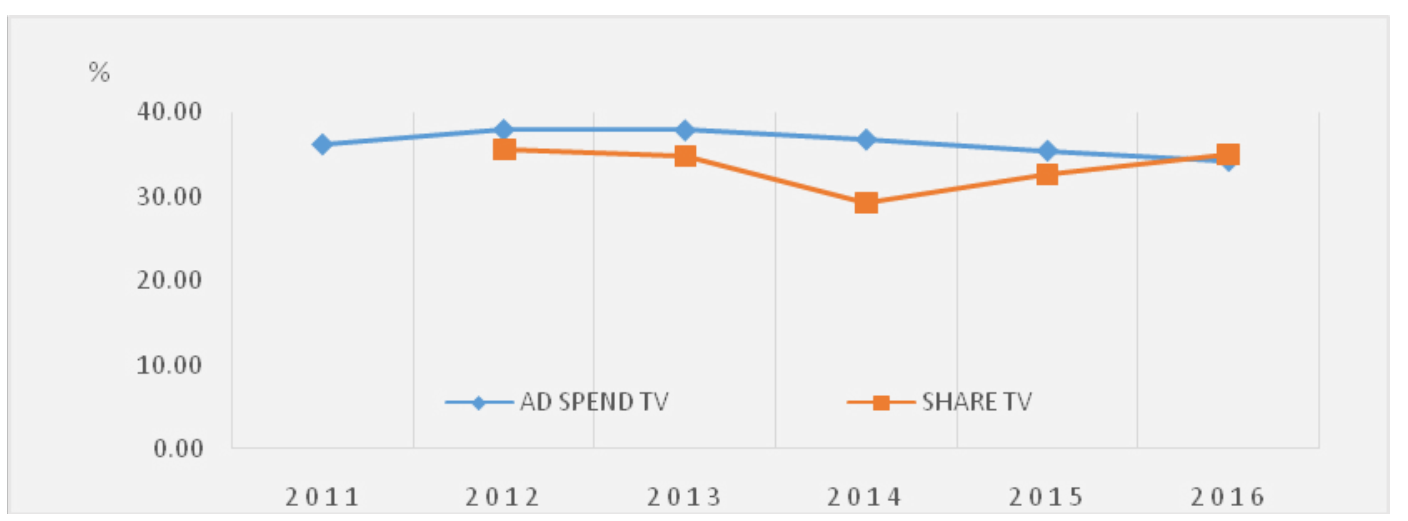

Gambar 1. Proporsi Penguasaan Audiens dan Iklan Grup Global Mediacom Sumber: Diolah dari data Nielsen Media 2011-2016 
tahun 2015. Salah satu sumber penurunan disebabkan oleh unit usaha pertelevisian berbasis pelanggan (PT MNC Sky Vision Tbk), khususnya kinerja beberapa televisi berlangganan (Indovision, Okevison, Top TV). Data laporan keuangan perusahaan menunjukkan kerugian pada catatan rugilaba korporasi.

Melalui berbagai kondisi yang dialaminya, bisnis pertelevisian grup Global Mediacom menjadi tidak lagi semenarik beberapa tahun sebelumnya. Perhitungan berbagai rasio finansial, misalnya, menunjukkan tingkat pengembalian aset dari keuntungan yang diraih menjadi semakin panjang, kewajiban yang dipikul menjadi semakin besar dibandingkan jumlah aset yang dimiliki, serta profit margin yang semakin mengecil dibandingkan tahuntahun sebelumnya (Tabel 3).
Apabila Grup Global Mediacom tengah dihadapkan pada tekanan ekonomi akibat penurunan pendapatan usaha, Grup Emtek hingga akhir tahun 2016 menunjukkan kondisi yang sedikit berbeda. Sekalipun penurunan penguasaan share audiens terjadi semenjak tahun 2014 namun dari sisi proporsi penguasaan pasar iklan justru periode waktu yang sama menunjukkan tren peningkatan (Gambar 2).

Pada grup ini, penurunan proporsi penguasaan audiens terbesar terjadi pada stasiun televisi SCTV. Dari proporsi penguasaan audiens sebesar 16,2 persen di tahun 2014 menjadi 11,5 persen tahun 2016. Akan tetapi, kondisi penurunan tersebut diikuti oleh kenaikan penguasaan pasar audiens oleh stasiun televisi Indosiar, yang konsisten meningkat semenjak tahun 2013.

Tabel 3. Kinerja Keuangan PT Global Mediacom Tbk 2011-2016

\begin{tabular}{lrrrrrr}
\hline Kinerja Keuangan & $\mathbf{2 0 1 1}$ & $\mathbf{2 0 1 2}$ & $\mathbf{2 0 1 3}$ & $\mathbf{2 0 1 4}$ & $\mathbf{2 0 1 5}$ & $\mathbf{2 0 1 6}$ \\
\hline Aset (Milyar Rp) & $15.111,6$ & $19.995,53$ & $21.069,47$ & $25.365,21$ & $26.613,97$ & $24.624,43$ \\
Revenue (Milyar Rp) & $7.162,94$ & $8.925,42$ & $10.019,98$ & $10.657,15$ & $10.572,83$ & $10.459,64$ \\
Profit (Milyar Rp) & $1.163,77$ & $1.993,49$ & $1.029,65$ & $1.290,01$ & 301,50 & 786,54 \\
Return on Asset (\%) & 5,16 & 6,50 & 2,94 & 2,77 & 0,26 & 0,83 \\
Total Liabilities to Assets & 0,28 & 0,29 & 0,37 & 0,37 & 0,42 & 0,44 \\
Net Profit Margin (\%) & 10,88 & 14,55 & 6,19 & 6,60 & 0,66 & 1,95 \\
\hline
\end{tabular}

Sumber: Diolah dari Laporan Tahunan teraudit PT Global Mediacom Tb (2011-2017)

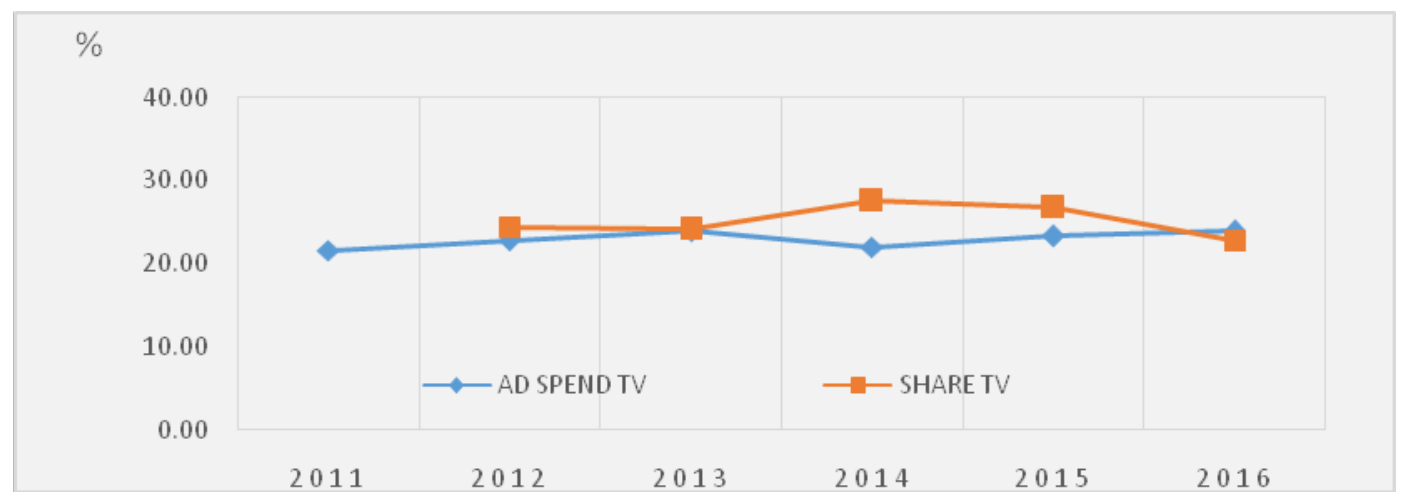

Gambar 2. Proporsi Penguasaan Audiens dan Iklan Grup Emtek Sumber: Diolah dari data Nielsen Media 2011-2016 
Tabel 4. Kinerja Keuangan PT Elang Mahkota Teknologi Tbk 2011-2016

\begin{tabular}{lrrrrrr}
\hline Kinerja Keuangan & $\mathbf{2 0 1 1}$ & $\mathbf{2 0 1 2}$ & $\mathbf{2 0 1 3}$ & $\mathbf{2 0 1 4}$ & $\mathbf{2 0 1 5}$ & $\mathbf{2 0 1 6}$ \\
\hline Aset (Milyar Rp) & $7.135,05$ & $10.177,89$ & $12.825,63$ & $19.888,68$ & $17.500,27$ & $20.965,15$ \\
Revenue (Milyar Rp) & $4.136,53$ & $4.681,03$ & $5.792,49$ & $5.983,94$ & $4.783,00$ & $5.354,49$ \\
Profit (Milyar Rp) & 738,04 & $1.029,49$ & $1.473,53$ & $1.488,85$ & $1.821,72$ & 731,09 \\
Return on Asset (\%) & 8,50 & 7,80 & 8,00 & 5,50 & 7,60 & 8,50 \\
Total Liabilities to Assets & 0,33 & 0,23 & 0,27 & 0,18 & 0,12 & 0,33 \\
Net Profit Margin (\%) & 14,70 & 16,90 & 17,80 & 18,30 & 20,70 & 14,70 \\
\hline
\end{tabular}

Sumber: Diolah dari Laporan Tahunan teraudit PT Elang Mahkota Teknologi Tbk (2011-2017)

Dari sisi kinerja keuangan, pelemahan ekonomi juga dialami oleh grup ini, khususnya pada tahun 2015. Saat itu, pendapatan usaha menurun. Aset yang dikelola pun menurun. Setahun selanjutnya (2016), perbaikan kondisi terjadi. Peningkatan pendapatan dan aset berlangsung, sekalipun besaran profit yang diraih masih lebih rendah dibandingkan dengan tahun-tahun sebelumnya. Dengan kinerjanya itu, managemen terlihat cukup efisien memanfaatkan aset yang dimiliki untuk mendatangkan keuntungan. Begitu pula dengan tanggungan kewajiban yang dipikul dibandingkan dengan besaran aset masih relatif kecil.

Akan tetapi, kondisi terkini menunjukkan profit yang cenderung semakin menurun. Hingga triwulan ke-3 (September 2017) profit yang diciptakan baru sebesar Rp 464 milyar, atau 63 persen dari perolehan sepanjang tahun 2016 lalu. Hingga akhir tahun 2017 ini, tampaknya cukup berat untuk menyamakan kinerja keuangan dengan pencapaian 2016 lalu.

Dibandingkan dengan kedua grup korporasi di atas, Grup Visi Media Asia memiliki kondisi yang agak berbeda. Grup korporasi ini semenjak tahun 2011 lalu mencatatkan peningkatan penguasaan pasar audiens dan pasar iklan secara bersamaan.
Dari dua stasiun televisi yang mereka kuasai, ANTV menjadi penyumbang terbesar sejalan dengan keberhasilan dalam meramu konten tayangan televisi bagi masyarakat. Pada tahun 2012 lalu, share audiens ANTV masih tercatat sebesar 6,9 persen dan mendudukkan stasiun televisi ini pada urutan ke-5, setelah RCTI, SCTV, MNC TV, dan Indosiar. Semenjak tahun 2014 hingga meningkat secara konsisten dan pada tahun 2016 mampu meraih share audiens 14 persen, menduduki urutan kedua setelah RCTI. Bahkan, paruh awal 2017 menjadi market leader, menggeser RCTI.

Kondisi yang berbeda pada stasiun TVOne, televisi yang sebelumnya mengkhususkan siarannya pada tayangan berita. Sekalipun tercatat sebagai pemimpin pasar penonton televisi berita, namun semenjak tahun 2012 hingga kini TVOne belum memberikan kontribusi yang signifikan bagi kehidupan bisnis Grup Visi Media Asia.

Pelemahan kondisi ekonomi turut berpengaruh terhadapkinerja grup Visi Media Asia, terutama tercermin dalam penurunan nilai iklan yang diraih setahun terakhir. Namun, jika dilihat dari share penguasaan pasar iklannya, justru menunjukkan sedikit peningkatan (Gambar 3). 


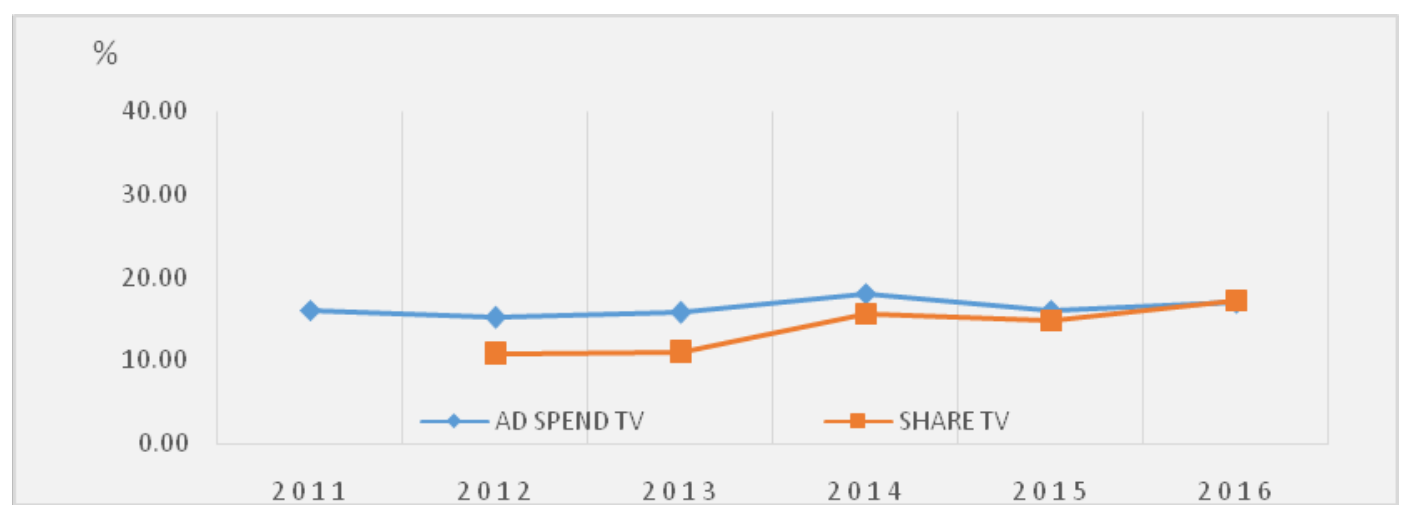

Gambar 3. Proporsi Penguasaan Audiens dan Iklan Grup Visi Media Asia Sumber: Diolah dari data Nielsen Media 2011-2016

Sekalipun menunjukkan peningkatan penguasaan pasar audiens dan pasar iklan, Grup Visi Media masih menyimpan berbagai kendala dalam pengelolaan keuangan. Kondisi demikian tergambarkan dalam kinerja keuangan grup ini, terlebih jika dibandingkan dengan kondisi Grup Global Mediacom dan Emtek. Dari sisi aset dan revenue, Grup Visi Media Asia memang berhasil mencatatkan peningkatan dari tahun ke tahun. Hanya, dari sisi profit tergolong fluktuatif. Pada tahun 2015, grup ini mencatatkan kerugian sebesar Rp 482 milyar. Namun setahun berikutnya, mampu meningkatkan profit sebesar Rp 477 milyar. Catatan terakhir, hingga akhir Juni 2017, grup ini membukukan profit sebesar Rp 243,8 milyar (Tabel 5).

Mencermati berbagai perhitungan rasio kinerja keuangannya, terlihat besarnya beban ekonomi yang ditanggung Grup Visi Media Asia. Kemampuan manajemen tahuntahun terakhir dalam menciptakan profit dari modal yang dikelola relatif kecil. Di sisi lain, kewajiban yang harus ditanggung korporasi media ini relatif besar jika dibandingkan dengan aset yang dikuasai. Kendati demikian, tahun 2016 net profit marjin yang dihasilkan terbesar dibandingkan dengan tahun-tahun sebelumnya. Adanya kondisi seperti ini, segenap performa positif yang berhasil diciptakan harus terbebani oleh kewajiban finansial yang juga besar.

Ketiga grup korporasi media televisi di atas kini tetap menjadi penguasa pasar audiens dan iklan pertelevisian dengan penguasaan total hingga 75 persen. Lima tahun terakhir, proporsi penguasaan pasar relatif tidak tergantikan, tetap terkonsentrasi pada ketiga pelaku. Berdasarkan hal

Tabel 5. Kinerja Keuangan PT Visi Media Asia Tbk 2011-2016

\begin{tabular}{lrrrrrr}
\hline Kinerja Keuangan & $\mathbf{2 0 1 1}$ & $\mathbf{2 0 1 2}$ & $\mathbf{2 0 1 3}$ & $\mathbf{2 0 1 4}$ & $\mathbf{2 0 1 5}$ & $\mathbf{2 0 1 6}$ \\
\hline Aset (Milyar Rp) & $2.417,60$ & $2.993,40$ & $5.303,08$ & $6.156,44$ & $6.206,14$ & $6.836,55$ \\
Revenue (Milyar Rp) & 992,60 & $1.214,40$ & $1.674,37$ & $2.272,68$ & $2.108,74$ & $2.685,71$ \\
Profit (Milyar Rp) & 26,30 & 72,90 & 105,79 & 173,47 & $-482,29$ & 477,00 \\
Return on Asset (\%) & 0,10 & 2,40 & 1,99 & 2,34 & $-8,25$ & 5,98 \\
Total Liabilities to Assets & 0,34 & 0,44 & 0,61 & 0,57 & 0,65 & 0,62 \\
Net Profit Margin (\%) & 2,65 & 5,83 & 6,32 & 6,35 & $-24,27$ & 15,22 \\
\hline
\end{tabular}

Sumber: Diolah dari Laporan Tahunan teraudit PT Visi Media Asia Tbk (2011-2017) 
tersebut, pelemahan laju perekonomian tidak mengubah struktur pasar yang terbentuk. Struktur pasar pertelevisian yang sangat terkonsentrasi tersebut hanya menyisakan sedikit ruang bagi para pelaku industri media lainnya, lima grup korporasi media, untuk bersaing dalam penguasaan pasar.

Di antara kelima grup korporasi media, Grup Trans Media (CT Corp) paling tergolong signifikan pola penguasaan pasarnya. Pengendalian terhadap Trans TV dan Trans7, sepanjang tahun 2016 grup ini mampu menguasai hingga 13,6 persen pasar audiens dan 15,9 persen pasar iklan. Akan tetapi, besaran proporsi yang dikuasai Grup Trans Media tersebut dapat dibaca sebagai suatu persoalan bagi grup ini. Dikatakan demikian, oleh karena jika ditelusuri sepanjang lima tahun terakhir, terjadi penurunan share audiens dan iklan. Sebagai gambaran, tahun 2011-2012 lalu grup ini mampu menguasai share audiens dan iklan di atas 20 persen (Gambar 4).

Baik Trans TV maupun Trans 7 memiliki kinerja yang relatif mirip, keduanya mengalami penurunan. Penurunan kedua stasiun televisi tersebut menjadi persoalan bagi grup ini, mengingat pada masa sebelumnya performa Trans TV dan Trans 7 tergolong tinggi, sempat berada pada posisi lima besar. Saat ini kedua televisi tersebut hanya mampu berada pada urutan tujuh besar.

Penguasaan dominan oleh keempat grup korporasi di atas, menimbulkan pertanyaan bagaimana dengan kinerja pasar grup media lainnya? Pasar media pertelevisian hanya menyisakan sekitar 10 persen saja audiens share dan iklan televisi. Porsi tersebut diperebutkan oleh para pelaku pasar yang terbilang baru dalam industri pertelevisian. Menariknya, sekalipun tampak kecil proporsi yang dikuasai, namun dari waktu ke waktu cenderung terjadi peningkatan (Gambar 5).

Peningkatan yang tergolong signifikan terjadi pada stasiun TV NET, RTV, dan Kompas TV. Pada saat kemunculannya, NET masih menguasai di bawah satu persen share audiens, namun saat ini beranjak menjadi sekitar tiga persen. Sementara, RTV dan Kompas TV sekalipun meningkat namun masih di bawah kisaran dua persen. Selain share audiens, ketiga stasiun TV pun juga mengalami peningkatan iklan, termasuk setelah melampaui pelemahan ekonomi di tahun 2015.

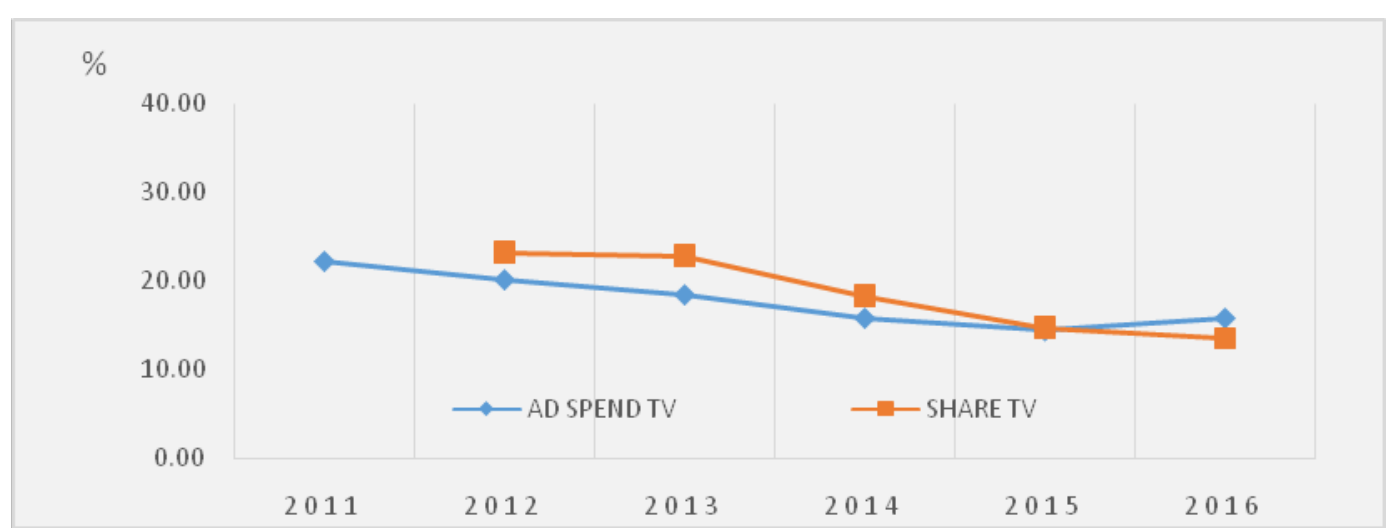

Gambar 4. Proporsi Penguasaan Audiens dan Iklan Grup Trans Media Sumber: Diolah dari data Nielsen Media 2011-2016 


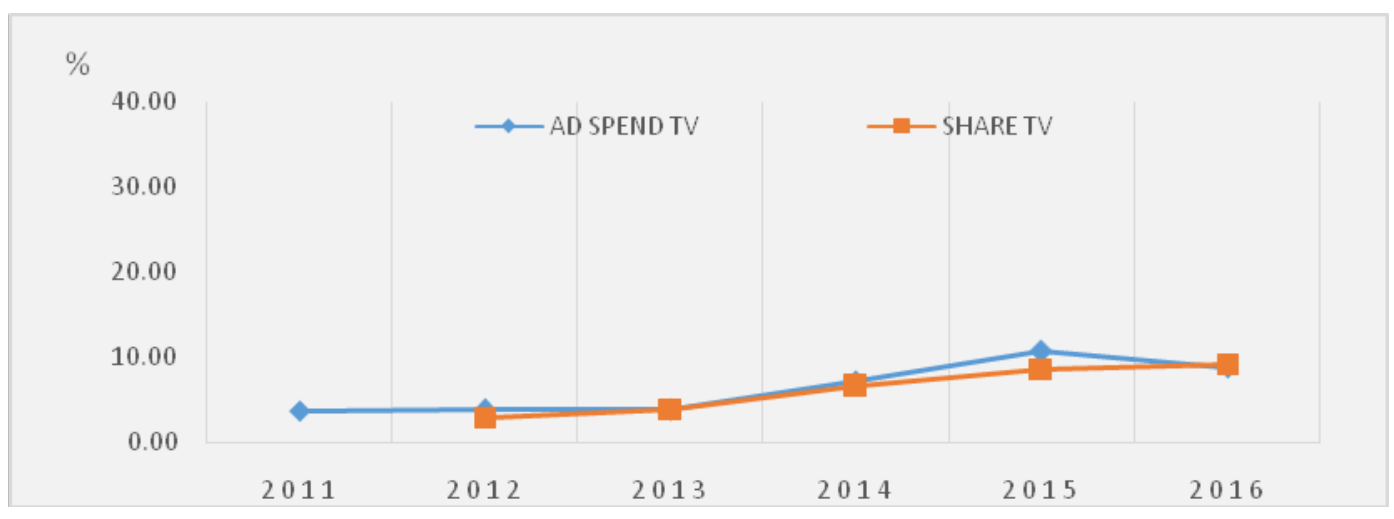

Grafik 5. Proporsi Penguasaan Audiens dan Iklan Grup Media Lainnya Sumber: Diolah dari data Nielsen Media 2011-2016

Kondisi yang berbeda terjadi pada pelaku lama industri, Metro TV. Sepanjang lima tahun terakhir, televisi yang mengkhususkan pada pemberitaan tersebut tidak mengalami peningkatan kinerja. Bahkan beberapa tahun terakhir, cenderung menurun. Tahun 2016, porsi penguasaan share audiens di bawah dua persen, tidak banyak berbeda dengan kinerja televisi publik, TVRI. Proporsi penguasaan iklan pun menurun dibandingkan tahun-tahun sebelumnya. Saat ini, hanya mampu menguasai hingga empat persen dari total belanja iklan pertelevisian.

Dinamika pasar yang berlangsung dalam kehidupan industri media pertelevisian di atas mengonfirmasikan kekuatan kapital dan sirkulasinya yang sejauh ini belum tergantikan. Sebagaimanakapitalyang dikonsepsikan Marx (1867, 1992), proses pengakumulasian terusmenerus berlangsung yang didasarkan pada penciptaan surplus nilai produksi. Kapital yang didayagunakan dalam industri pertelevisian sejauh ini masih memberikan surplus nilai yang memampukan masing-masing pelaku pasar untuk lebih mengakumulasikannya dalam bentuk-bentuk kapital media baru.

Pola pengakumulasian kapital yang berlangsung berjalan dalam perluasan ke- pemilikan media sebagai bagian dari pengintegrasian kepemilikan, baik secara horisontal, vertikal maupun diagonal. Pengintegrasian kepemilikan semacam ini terbukti menjadi senjata ampuh bagi persaingan. Sebagaimana dipaparkan di atas, dinamika persaingan yang terbentuk dalam pasar industri pertelevisian di negeri ini tergolong ketat yang melahirkan beberapa perubahan penguasaan pasar iklan maupun audiens. Begitu pula, pelemahan kondisi perekonomian membuat tekanan terhadap pasar industri. Akan tetapi, sejalan dengan pengintegrasian kepemilikan yang membentuk grup-grup korporasi media besar, perubahan-perubahan tersebut menjadi kurang signifikan dirasakan. Tiga grup korporasi media dengan kepemilikan berbagai stasiun televisi berhasil mempertahankan pola penguasaan pasar industri.

Berdasarkan besaran porsi penguasaan pasarnya, dominasi ketiga grup korporasi media sulit tergantikan. Pada konsepsi ekologi media (Dimmick, 2003:39), ketiga grup media tersebut tergolong memiliki competitive superiority yang kuat hingga mampu menjaga porsi penguasaan pasar industri media. Sekalipun dalam beberapa pelaku industri terdapat peningkatan porsi penguasaan pasar 
sebagaimana yang ditunjukkan oleh NET, RTV, dan Kompas TV, namun masih tergolong kecil dan kurang signifikan dibandingkan dengan porsi kekuasaan tiga grup korporasi terbesar.

\section{Simpulan}

Perlemahan kondisi perekonomian global dan nasional telah berimplikasi pada kondisi ekonomi industri pertelevisian nasional. Indikator penurunan laju pertumbuhan dan volume belanja iklan pertelevisian tahun-tahun belakangan ini mengindikasikan ancaman terhadap prospek pasar industri pertelevisian nasional. Hampir sebagian besar pelaku pasar pertelevisian terdampak, sejalan dengan penurunan penerimaan revenue iklan mereka.

Dinamika ekonomi industri yang terjadi belum berarti mengubah konfigurasi struktur pasar yang terbentuk. Kajian ini menunjukkan, karakteristik pasar industri pertelevisian yang terbentuk, baik pasar audiens dan pasar iklan, tetap terkonsentrasi pada penguasaan tiga pelaku pasar (the big three) yaitu Grup Global Mediacom, Grup EMTEK, dan Grup Visi Media Asia. Konsentrasi kapital media dalam berbagai format integrasi kepemilikan media membuat ketiga grup tersebut mampu mempertahankan pasar industri yang bersifat oligopolistik. Sekalipun beberapa kinerja keuangan ketiga grup korporasi tersebut turut menurun, namun tetap menguasai hingga tiga perempat bagian pasar audiens dan iklan nasional.

Penguasaan dominan tiga grup media membangun entry barrier pasar industri dan cenderung membuat pola persaingan pasar semakin tidak kompetitif. Pelaku industri di luar ketiga grup tersebut hingga sejauh ini tetap tidak mampu mengambil alih peran ketiga grup tersebut. Pada perspektif keragaman kepemilikan media, realitas industri media yang sangat terkonsentrasi pada segelintir pelaku industri ini sangat potensial menjadi ancaman terhadap idealisasi demokratisasi media di negeri ini. Potensi ancaman semacam ini tidak terulas dan menjadi keterbatasan dalam kajian ini.

\section{Daftar Pustaka}

Albarran, A.B. (1996). Media Economics: Understanding Markets, Industries and Concepts. Iowa: Iowa State University Press.

Albarran, A.B., \& Mierzejewska, B.I. (2004). Media Concentration in the US and Europian Union: A Comparative Analysis. Paper Presented at the $6^{\text {th }}$ World Media Economics Conference, HEC Montreal, Canada.

Armando, A. (2016). Televisi Indonesia di Bawah Kapitalisme Global. Jakarta: Penerbit Buku Kompas.

Dimmick, JW. (2003). Media Competition and Coexistence-The Theory of the Niche. London: Lawrence Erlbaum Associates.

Ed Hollander, Leen d'Haenens \& Jo Bardoel (2009). Television performance in Indonesia: steering between civil society, state and market, Asian Journal of Communication, 19:1,39-58

Ishadi S.K. (2002). Media dan Kekuasaan: Televisi di Hari-hari Terakhir Presiden Soeharto. Jakarta: Penerbit Buku Kompas.

Kitley, P. (2003). Television, regulation and civil society in Asia. London, New York: Routledge Curzon.

Knoche, Manfred. (1999). The Media Industry's Structural Transformation in Capitalism and TheRole of the State: Media Economics in the Age of Digital Communications. Triple C 14 (1): 1-47. 
Marx, Karl. (1867, 1992). Capital: A Critique of Political Economy: The Process of Circulation of Capital. London: Penguin Classics

Mosco, Vincent. (1996, 2009). The Political Economy of Communication. London: Sage.

Picard, R.G, (1989). Media Economics. Beverly Hills: Sage.

Picard, R.G. (2009, 1988). Measures of Concentration in The Daily Newspaper Industry. Journal of Media Economics, 1:1,61-74.

Sen, Krishna; David T.Hill. (2000). Media, Culture and Politics in Indonesia. Melbourne: OxfordUniversity Press.

Wirth, M.O., \& Bloch, H (1995). Industrial Organization Theory and Media Industry Analysis. Journal of media Economics, 8 (2), $15-26$

Young, D.P.T. (2000). Modelling Media Markets: How Important is Market Structure? Journal of Media Economics, 13: 27-44.

\section{Laporan Penelitian}

AsosiasiPenyelenggara JasaInternetIndonesia: Survei Internet APJII 2016. (2016). Available from https://apjii.orid/content/ read/39/264/Survei-Internet-APJII-2016

Lim, Merlyna (2012). The League of Thirteen Media Concentration in Indonesia. Participatory Media Lab., Arizona State University \& Ford Foundation.

Nugroho, Y., Putri, D.A., \& Laksmi, S. (2012). Memetakan Lanskap Industri Media Kontemporer di Indonesia. Jakarta: CIPG dan HIVOS.
Price Waterhouse Coopers: Perspectives from the Global Entertainment and Media Outlook 2017-2021 (2017). Available from https://www.pwc.com/gx/en/entertainmentmedia/pdf/outlook-2017-curtain-up.pdf

\section{Dokumen Resmi}

Badan Pusat Statistik: Indikator Strategis Nasional. (2017). Available from: https:// www.bps.go.id/QuickMap?id

Laporan Keuangan Konsolidasi (2011, 2012, 2013, 2014, 2015, 2016, 2017/Q3) PT. Global Mediacom Tbk dan Entitas Anak.

Laporan Keuangan Konsolidasi (2011, 2012, 2013, 2014, 2015, 2016, 2017/Q3) PT. Elang Mahkota Teknologi Tbk dan Entitas Anak.

Laporan Keuangan Konsolidasi (2011, 2012, 2013, 2014, 2015, 2016, 2017/Q2) PT. Visi Media Asia Tbk dan Entitas Anak.

Nielsen Media (2015, 1997). Media Scene 1997-2015. Jakarta: ITKP Mediatama Advertising

\section{Artikel Surat Kabar}

Basri, M.C. (2015, October 15). Kemandekan Ekonomi. Kompas, p.6.

Basri, M.C. (2016, June 16). Memacu Pertumbuhan Ekonomi. Kompas, p.6

Basri, M.C. (2017, August 1). Pembiayaan Pembangunan. Kompas, p.6.

Dewan Pers dan 47 Ribu Media di Indonesia. (2017, July 15). Available from http://news. liputan6.com/read/3023298/dewan-persdan-47-ribu-media-di-indonesia

DJiwandono, S. (2015, Sept 17). Tongkok, AS, dan Kita. Kompas, p.6.

Prasetyantoko, A. (2014, May 16). Pertumbuhan dan Kemandirian. Kompas, p.6. 